\title{
Unilateral Revocability in Wightman: Fixing Article 50 with Constitutional Tools
}

\author{
ECJ 10 December 2018, Case C-621/18, Andy Wightman and \\ Others v Secretary of State for Exiting the European Union
}

\author{
Jure Vidmar*
}

\section{INTRODUCTION}

On 3 October 2018, Scotland's Court of Session, Inner House, First Division made a reference to the Court of Justice of the European Union for a preliminary ruling on the following question:

Where, in accordance with Article 50 [TEU], a Member State has notified the European Council of its intention to withdraw from the European Union, does EU law permit that notice to be revoked unilaterally by the notifying Member State; and, if so, subject to what conditions and with what effect relative to the Member State remaining within the European Union? ${ }^{1}$

Following the expedited proceedings, a Full Court ruling was delivered merely three months later, on 10 December 2018. This analysis will scrutinise the Court's reasoning pertaining to the admissibility and substance of the case. Despite the political sensitivity of Wightman, this analysis will focus only on the ruling's legal dimensions.

In the admissibility phase, the Court of Justice considered the argument of the United Kingdom government that the question was merely hypothetical and

*Professor of Public International Law, Faculty of Law, Maastricht University.

${ }^{1}$ ECJ 10 December 2018, Case C-621/18, Andy Wightman and Others v Secretary of State for Exiting the European Union, para. 16 [hereinafter: Wightman].

European Constitutional Law Review, 15: 359-375, 2019

(C) 2019 The Authors. This is an Open Access article, distributed under the terms of the Creative Commons Attribution licence (http://creativecommons.org/licenses/by/4.0/), which permits unrestricted re-use, distribution, and reproduction in any medium, provided the original work is properly cited.

doi:10.1017/S1574019619000142 
academic in nature and that there was no dispute. ${ }^{2}$ Deciding that the referred question was admissible, ${ }^{3}$ the Court rejected this view without itself providing much reasoning as to why the question might not be hypothetical.

On substance, the judgment noted that Article 50 'does not explicitly address the subject of revocation. It neither expressly prohibits nor expressly authorises revocation'. ${ }^{4}$ The judgment proceeded with argumentation to conclude that an Article 50 withdrawal notification is unilaterally revocable following a democratic procedure and in accordance with domestic constitutional requirements as long as it is given before the expiry of the two-year period by written notice to the European Council. ${ }^{5}$ This conclusion is underpinned by two central arguments: (i) 'An intention is, by its nature, neither definitive nor irrevocable', 6 and (ii) 'the interpretation of a provision of EU law requires that account be taken not only of its wording and the objectives it pursues, but also of its context and the provisions of EU law as a whole'?

Article 50(2) TEU opens with: 'A Member State which decides to withdraw shall notify the European Council of its intention'. ${ }^{8}$ The Court did not recognise a treaty law term of art in the word intention, but instead subscribed to the meaning of the word in plain language, holding that the notice-giving state retains the right to change its 'intentions'. Furthermore, the Court corroborated its conclusions with references to the Vienna Convention on the Law of Treaties. Some of the interpretations of the Vienna Convention are at least debatable and may even undermine the Court's own interpretation of the word intention.

The reasoning became much more persuasive when the Court looked beyond the textual reading of Article $50 \mathrm{TEU}$ and made a constitutional argument. Textually, Article 50 reads like a typical treaty withdrawal mechanism. However, acting as the EU Constitutional Court, the Court of Justice looked beyond the textual reading of Article 50, fixing the faulty mechanism for separation from a constitutionalised polity.

\section{BACKGROUND OF THE REFERENCE}

In December 2017, a group of seven Scottish members of the Scottish, United Kingdom, and European Parliaments, headed by Andy Wightman, a member of

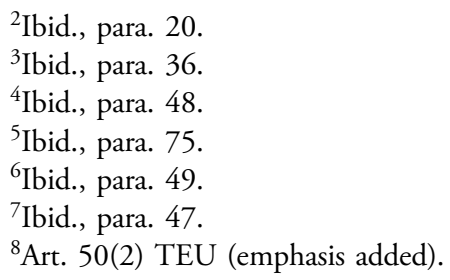


the Scottish Parliament, brought a petition for judicial review to the Scottish Court of Session, claiming that the UK could unilaterally withdraw its Article 50(2) TEU notification of intention to exit the EU. ${ }^{9}$ They asked the Scottish court to make an Article 267 TFEU reference to the Court of Justice by way of an expedited procedure. That request was declined by the Outer House (first instance) of the Court of Session on 6 February 2018, with Lord Doherty arguing:

Given that neither Parliament nor the Government has any wish to withdraw the notification, the central issue which the petitioners ask the court to decide whether the UK could unilaterally withdraw the Article 50(2) notification - is hypothetical and academic. In those circumstances it is not a matter which this court, or the European Court of Justice, require to adjudicate upon. ${ }^{10}$

The Outer House decision was appealed to the Inner House (the appeals chamber) of the Court of Session, which found, on 20 March 2018, that the petition had 'significant problems' ${ }^{11}$, disagreeing, however, with the Lord Ordinary (first instance judge) that the petition had no 'real prospect of success'. ${ }^{12}$ As a result, the appeals instance recalled 'the interlocutor of the Lord Ordinary'13 and sent the case back to the Outer House for procedural and substantive hearings. ${ }^{14}$

On 8 June 2018, the Outer House (Lord Boyd) noted that the petitioners sought an answer from the Court of Session to the following question: 'Can ... [the Article $50 \mathrm{TEU}$ ] notice be unilaterally revoked by the UK acting in good faith such that the United Kingdom could continue to be a member of the European Union after 29 March 2019 on the same terms and conditions as it presently enjoys?' ${ }^{\prime 5}$ The Outer House dismissed the request, arguing that 'the question that is being asked is hypothetical. The facts upon which the European Court of Justice would be asked to give an answer could not at this stage be ascertained, simply because they have not occurred'. ${ }^{16}$ However, this was 15 days before the UK Parliament adopted the EU Withdrawal Act (23 June 2018), which in its section 13 regulates 'parliamentary approval of the outcome of negotiations with the EU'. ${ }^{17}$ Arguably, these circumstances made the situation somewhat less academic and hypothetical, as some of

\footnotetext{
${ }^{9}$ Outer House, Court of Session (Scotland) 6 February 2018 [2018] CSOH 8, para. 4.

${ }^{10}$ Ibid., para. 14.

${ }^{11}$ First Division, Inner House, Court of Session (Scotland) 20 March 2018 [2018] CSIH 18,

${ }^{12}$ Ibid., para. 32.

${ }^{13}$ Ibid., para. 34.

${ }^{14}$ Ibid., para. 34 .

${ }^{15}$ Outer House, Court of Session (Scotland) 8 June 2018 [2018] CSOH 61, para. 2.

${ }^{16}$ Ibid., para. 73.

${ }^{17}$ European Union (Withdrawal) Act 2018 (United Kingdom) c. 13.
} para. 28. 
the petitioners were members of the UK parliament and legislation now existed that required them to vote on the outcome of Brexit negotiations.

The petitioners appealed and on 21 September 2018, the Inner House of the Court of Session decided to make a reference to the Court of Justice pursuant to Article 267 TFEU, arguing:

It is clear, in terms of the European Union (Withdrawal) Act 2018, that MPs will be required to vote on whether to ratify any agreement between the UK Government and the EU Council. If no other proposal is proffered, a vote against ratification will result in the UK's departure from the EU on 29 March 2019; a date which is looming up. It seems neither academic nor premature to ask whether it is legally competent to revoke the notification and thus to remain in the EU. ${ }^{18}$

While it is true that a member of the UK Parliament may have had an interest in knowing which alternative proposals to the withdrawal agreement could be made in Parliament, this did not automatically make the substantive matter any less hypothetical. It was still a matter of political choice as to whether any given alternative Brexit proposal would be tabled. Rather than being presented with a genuine legal dispute, it appears that the court had been asked to give legal advice on whether any particular policy could - potentially - be pursued in the future.

\section{AdMissibility: A GeNUINE QUeSTION OF LAW?}

It was the position of UK government in the proceedings before the Court of Justice that the case was inadmissible due to its hypothetical nature ${ }^{19}$ and that absence of a dispute 'since the question referred addresses events that have not occurred and may not occur'. ${ }^{20}$ The European Commission agreed that the question was hypothetical, as 'the Court's answer to the question referred will not produce any binding effects on the parties to the main proceedings'. ${ }^{21}$

The admissibility part of the judgment recalled that it is, in principle, up to the referring court to assess whether valid reasons exist for a preliminary ruling and that if 'the questions submitted concern the interpretation of a rule of EU law, the Court is in principle bound to give a ruling. ${ }^{22}$ But the Court also noted that it could refuse to rule, inter alia, 'where the problem is hypothetical'. ${ }^{23}$ At this point,

\footnotetext{
${ }^{18}$ First Division, Inner House, Court of Session (Scotland) 21 September 2018 [2018] CSIH 62,

${ }^{19}$ Wightman, supra n. 1, para. 36.

${ }^{20}$ Ibid., para. 21.

${ }^{21}$ Ibid., para. 25.

${ }^{22}$ Ibid., para. 27.

${ }^{23}$ Ibid., para. 28.
} para. 27. 
the admissibility part turned back to the referring court's assessment that the question represented 'a genuine and live issue, of considerable practical importance, and which has given rise to a dispute [recalling that] one of the petitioners and the two interveners, who are Members of the United Kingdom Parliament, must vote on the withdrawal of the United Kingdom from the European Union. ${ }^{24}$ The Court accepted this assessment without much further reasoning, dismissed the UK government's objections, and concluded that the case was admissible. ${ }^{25}$

The admissibility argument can be summarised as follows: (i) it is, in principle, up to the referring court to decide whether a preliminary ruling is needed; (ii) the Court must rule, in principle, unless the questions are hypothetical; (iii) a question is not hypothetical because the referring court says so. There is an element of circularity in this reasoning, or at least an absence of critical engagement with the referring court's argumentation. The Court seems to have happily accepted the referring court's reasoning without providing much of an assessment as to why the question was not hypothetical.

This is problematic for two reasons. First, the referring court itself had not sufficiently explained why the matter was not hypothetical. ${ }^{26}$ The EU Withdrawal Act of 23 June 2018 instituted parliamentary approval of a withdrawal agreement that may perhaps have made revocation of the Article 50 notification politically somewhat more likely, although the issue had not become any less hypothetical in law. Second, "[a]ccording to settled case law, the Court may refuse to rule on a question referred for a preliminary ruling ... where the problem is hypothetical'. ${ }^{27}$ The Court of Justice could, thus, have scrutinised the legal circumstances of the case independently of the referring court's assessment and provided its own reasoning as to why the case was not hypothetical.

As the Court of Justice stated in Foglia v Novello II, and later affirmed in a set of other cases, ${ }^{28}$ its role is:

not that of delivering advisory opinions on general or hypothetical questions but of assisting in the administration of justice in the Member States. It accordingly does not have jurisdiction to reply to questions of interpretation which are submitted to it within the framework of procedural devices arranged by the parties in order to induce the Court to give its views on certain problems of Community law which

${ }^{24}$ Ibid., para. 29.

${ }^{25}$ Ibid., para. 36.

${ }^{26}$ See supra n. 19.

${ }^{27}$ N. Wahl and L. Prete, 'The Gatekeepers of Article 267 TFEU: On Jurisdiction and Admissibility of References for Preliminary Rulings', 55 Common Market Law Review (2018) p. 511 at p. 513.

${ }^{28} \mathrm{Ibid}$. 
do not correspond to an objective requirement inherent in the resolution of a dispute. ${ }^{29}$

In Wightman, credible objections were raised stating that the case was hypothetical in nature and that there was no legal dispute at hand. ${ }^{30}$ It is noteworthy that the question posed by the petitioners to the Scottish Court of Session was substantially identical to the question referred to the Court of Justice, ${ }^{31}$ and that the remedy sought by the petitioners 'on return of ... [the] reference from the CJEU ... [was] a declarator from ... [the Scottish Court of Session] specifying whether, when and how the [Article $50 \mathrm{TEU}$ ] notification ... can unilaterally be revoked by the United Kingdom'. ${ }^{32}$ At the very least, this begs the question of why Wightman could not, in terms of Foglia v Novello II, be considered a procedural device to secure an advisory opinion from the Court of Justice. Although the Court's answer might potentially shape future policy choices and could even have an impact on legislation tabled before the UK Parliament, the legal dispute it was meant to settle remains unclear. At the very least, the Court of Justice insufficiently addressed these concerns.

\section{'INTENTIONS ARE NOT DEFINITE AND MAY CHANGE'}

One of the principal substantive underpinnings of the judgment is the sovereign will of states. ${ }^{33}$ The Court argued that 'a State cannot be forced to accede to the European Union against its will, neither can it be forced to withdraw from the European Union against its will'. ${ }^{34}$ This is certainly beyond dispute; more controversial is the question of why a state should be considered to have been forced out of the EU if it had, as an expression of its sovereign will, chosen to give an Article 50 notification in the first place. The answer to this question would seem to depend on the Court's interpretation of the word intention in Article 50(2) TEU.

The judgment recalled the division between the three steps of an EU withdrawal as outlined in the Court's judgment in Minister for Justice and Equality v RO: (i) notification of the intention to withdraw; (ii) negotiations for and conclusion of the withdrawal agreement; and (iii) the actual

\footnotetext{
${ }^{29}$ ECJ 16 December 1981, Case 244/80, Pasquale Foglia v Mariella Novello, para. 18 [hereinafter Foglia v Novello].

${ }^{30}$ See supra n. 19.

${ }^{31}$ See supra $\mathrm{nn} .1$ and 15.

${ }^{32}$ Outer House, Court of Session (Scotland) 8 June 2018 [2018] CSOH 61, para. 8(b).

${ }^{33}$ Wightman, supra n. 1, para. 50.

${ }^{34}$ Ibid., para. 65.
} 
withdrawal..$^{35}$ The Court of Justice then followed the reasoning of Advocate General Campos Sánchez-Bordona, who argued that Article 50(2)

states that 'a Member State which decides to withdraw shall notify the European Council of its intention', thereby activating the second phase of the procedure. The provision refers to the notification of the 'intention' to withdraw, and not to withdrawal itself, because withdrawal may only occur after the agreement is reached or, in the absence of an agreement, after two years have elapsed. ${ }^{36}$

Minister for Justice and Equality v $R O$ was a decision on a preliminary ruling requested by the Irish High Court concerning the interpretation of Article 50 TEU in the context of the European Arrest Warrant and the execution by Ireland of two arrest warrants issued by the UK. In that case, the Court thus drew a fine line between 'the notification of the intention to withdraw' and the 'withdrawal itself'. In the Wightman Opinion, the Advocate General drew an even finer distinction by holding that intentions are not definite and may change'. ${ }^{37}$ This position resonated throughout the judgment, in which a slightly different phrasing was used, although the meaning remained unchanged: 'An intention is, by its nature, neither definitive nor irrevocable. ${ }^{38}$

Departing momentarily from the premise that intentions are not definite and may change', it becomes clear how a state could be forced to leave the EU if it is unable to unilaterally revoke its intention to withdraw. For a period of two years, unless negotiated otherwise, notification remains legally detached from the actual withdrawal. Since the judgment specifically endorsed the Advocate General's Opinion in this respect, ${ }^{39}$ the Opinion merits a bit of further scrutiny at this point.

\section{The contractual logic}

When interpreting the word intention, the Advocate General drew an analogy with contract law:

As occurs in other areas of law, in the absence of an express prohibition or a rule which provides otherwise, whoever has unilaterally issued a declaration of intent

${ }^{35}$ Ibid., para. 51. See also ECJ 19 September 2018, Case C-327/18 PPU - R O, Minister for Justice and Equality $\mathrm{v} R O$, para. 46.

${ }^{36}$ ECJ 4 December 2018, Case C-621/18, Andy Wightman and Others v Secretary of State for Exiting the European Union, Opinion of AG SÆnchez-Bordona, para. 99 [hereinafter: the Wightman Opinion].

${ }^{37}$ Ibid., para. 100.

${ }^{38}$ Wightman, supra n. 1, para. 49.

${ }^{39}$ Ibid., para. 49. 
addressed to another party, may retract that declaration until the moment at which, by the addressee's acceptance, conveyed in the form of an act or the conclusion of a contract, it produces effects. ${ }^{40}$

This argument tacitly adopts the concept of a party's intention in the context of an offer in contract law. ${ }^{41}$ While an offer to enter into a contractual relationship can, of course, end up being rejected, or even unilaterally retracted by the offeror before being accepted, ${ }^{42}$ such an analogy, quite simply, does not correspond to the Article 50 situation. Intention is a core concept of contract law; it is defined as a determination to perform a particular act and create legal relations. ${ }^{43}$ As such, an intention creates a new legal situation.

If a contractual analogy is to be sought, the legal situation would appear to be more akin to the notice given by an employee with the intention of terminating his employment contract or a tenant whose intention is to terminate her tenancy agreement. If intending to quit, 'A' has given her 30-day notice, it is unlikely any labour court would recognise her right to unilaterally retract that notice on the $29^{\text {th }}$ day simply because her intention changed once she realised that she had not saved enough money for the coming year. ${ }^{44}$

When a party wishes to terminate a contract, contract rules commonly require that reasonable notice is given of the party's intention to terminate. ${ }^{45}$ Such a notice is not unilaterally retractable,${ }^{46}$ although many legal systems do recognise certain special circumstances such as, for example when an employee has given notice of intention to end an employment contract 'in the heat of the moment'. ${ }^{47}$ Even where such special circumstances do exist, no doctrine of contract law suggests that 'intentions are not definite and may change'. ${ }^{48}$ Article 50 textually adheres to the same contractual logic: a contracting party can give notification of its intention to withdraw; the notice period is two years, at which point withdrawal becomes final unless agreed otherwise. ${ }^{49}$ The text of Article 50 would appear

\footnotetext{
${ }^{40}$ The Wightman Opinion, supra n. 36, para. 98.

${ }^{41}$ Consider the following definition: 'An offer is an objective manifestation of intention ... by the offeror of a willingness to be bound by the terms proposed to the offeree ... as soon as the offeree signifies acceptance of the terms'. See M. Chen-Wishart, Contract Law (Oxford University Press 2017) p. 55.

${ }^{42}$ Ibid., p. 64-65.

${ }^{43}$ Ibid., p. 44.

${ }^{44} C f$ J. Holland and S. Burnett, Employment Law (Oxford University Press 2012) p. 213.

${ }^{45}$ See H. Collins, The Law of Contract (Cambridge University Press, 2003) p. 356.

${ }^{46}$ See Holland and Burnett, supra n. 44, p. 213.

${ }^{47}$ See M. Hogg, Promises and Contract Law: Comparative Perspectives (Cambridge University Press 2011) p. 22.

${ }^{48}$ Cf supra n. 37.

${ }^{49}$ Cf Art. 50 TEU.
} 
to be in line with the general theory and practice of contractual relations, whereas the Advocate General's pronouncement that notification of the intention to withdraw is unilaterally revocable because intentions may change is far from doctrinally persuasive. The judgment, nonetheless, adopted the problematic reasoning of the Advocate General. ${ }^{50}$

\section{The international treaty law reflection}

In order to establish the meaning of the term intention in international treaties, attention needs to be paid to the Vienna Convention. This is without prejudice to the general applicability of the Vienna Convention in this particular case. The aim here is rather to analyse how the term intention is understood as a general principle of treaty law.

Although the Vienna Convention uses the term intention multiple times, ${ }^{51}$ on no occasion does it support the view that intentions are not definite and may change..$^{52}$ Three examples will be considered here in greater detail.

Article 7(1) provides that ' $[\mathrm{a}]$ person is considered as representing a State ... [inter alia when] it appears ... that their [of the states concerned] intention was to consider that person as representing the State for such purposes and to dispense with full powers. ${ }^{53}$ It is thus clear that the term intention refers to the will of the state to be represented by a certain person. This does not, however, mean that a treaty signature becomes invalid simply because the state's intention to be represented by the person who signed the treaty has changed.

Article 18 provides that '[a] State is obliged to refrain from acts which would defeat the object and purpose of a treaty when ... it has signed the treaty ... until it shall have made its intention clear not to become a party to the treaty'. ${ }^{54}$ Again, intention does not mean something that may change; rather, it expresses the will to not be bound by treaty obligations. Article 20(4)(b) provides that 'an objection by another contracting State to a reservation does not preclude the entry into force of the treaty as between the objecting and reserving States unless a contrary intention is definitely expressed by the objecting State. ${ }^{55}$ In this article, the intention of the objecting states refers to their will not to be in treaty relations with the reserving state. It is thus clear that the interpretation 'intentions are not definite and may change' is not in line with the ordinary meaning of the word

${ }^{50}$ Cf supra n. 40.

${ }^{51}$ The term appears in the following Vienna Convention on the Law of Treaties articles: 7, 10, $14,20,25,28,29,40,41,56,58,59$.

${ }^{52}$ Cf supra n. 37.

${ }^{53}$ Art. 7(1) Vienna Convention on the Law of Treaties (emphasis added).

${ }^{54}$ Art. 18 Vienna Convention on the Law of Treaties (emphasis added).

${ }^{55}$ Art. 20(4)(b) Vienna Convention on the Law of Treaties (emphasis added). 
intention in treaty law. On the contrary, in international treaties, just as in contract law, intention means the determination of a party to perform a certain act with legal consequences.

This exercise demonstrates that the Court's interpretation of the word intention in Wightman is not compatible with the ordinary meaning of that term in the theory and practice of both contract and treaty law.

\section{Unilateral revocability and Article 68 Vienna Convention}

In order to corroborate its reasoning, the judgment of Court of Justice partially based the revocability argument on Article 68 of the Vienna Convention, which provides that 'A notification or instrument provided for in Article 65 or 67 may be revoked at any time before it takes effect ${ }^{56}{ }^{5}$ Before discussing the relevance of either Article 65 or 67 of the Vienna Convention to the Wightman case any further, it is important to underscore that the judgment referred to the Vienna Convention much more cautiously than did the Advocate General's Opinion, to which the Vienna Convention is of central importance. The EU itself is not a party to the Vienna Convention; nor are all of its member states. It is generally accepted that for the purposes of EU treaties, the Vienna Convention applies only to the extent that it is reflective of customary international law. ${ }^{57}$ Serious doubts exist, however, as to whether Article 65 reflects custom and, if so, which aspects thereof do so. Indeed, as the Court observed in Racke, it should be noted that the specific procedural requirements there [in Article 65] laid down do not form part of customary international law. ${ }^{58}$

The Wightman judgment bypassed this problem by stating that the notion that the conclusion of the withdrawal notification could be unilaterally revoked is corroborated by the provisions of the ... [Vienna Convention], which was taken into account in the preparatory work for the Treaty establishing a Constitution for Europe. ${ }^{59}$ By referring to the Vienna Convention only at the end of the judgment - and merely to 'corroborate' its previous conclusion - the judgment obviously does not put Article 68 of the Vienna Convention at the centre of its reasoning. Furthermore, it does not even apply the Vienna Convention directly; rather, it resorts to noting its effects in the context of the TEU and, even then, only by making mere mention of 'the preparatory work for the Treaty establishing a Constitution for Europe ${ }^{60}$ whence Article 50 TEU largely emanates. That way, the judgment avoids the problem already pointed out in

\footnotetext{
${ }^{56}$ Art. 68 Vienna Convention on the Law of Treaties.

${ }^{57}$ ECJ 16 June 1998, Case C-162/96, A. Racke GmbH \& Co., para. 24.

${ }^{58}$ Ibid., para. 59.

${ }^{59}$ Wightman, supra n. 1, para. 70.

${ }^{60} \mathrm{Ibid}$.
} 
Racke, i.e. that certain important aspects of the Vienna Convention may not be customary, while the Convention itself is not applicable as a treaty. ${ }^{61}$

\section{Does Article 68 Vienna Convention really apply?}

Even if one gives credence to the Court's manoeuvre of resorting to the Vienna Convention via the Constitution for Europe, Article 68 runs into yet another doctrinal problem. That article refers to Articles 65 and 67. In other words, it regulates unilateral revocability only if withdrawal occurs under these two articles. It is not clear, however, whether the Article 50 situation even falls under those two Vienna Convention mechanisms. Of particular relevance is Article 65(1), which reads:

A party which, under the provisions of the present Convention, invokes either a defect in its consent to be bound by a treaty or a ground for impeaching the validity of a treaty, terminating it, withdrawing from it or suspending its operation, must notify the other parties of its claim. The notification shall indicate the measure proposed to be taken with respect to the treaty and the reasons therefor. ${ }^{62}$

It is debatable whether this provision - and thus also Article 68 - applies to all treaties or only to those that do not contain specific withdrawal provisions. The Vienna Convention establishes such difference in Articles 54 and 56 respectively. ${ }^{63}$

The Vienna Convention was drafted by the United Nations International Law Commission. In its commentary to Article 64 of the International Law Commission Articles, which later became Article 65 of the Vienna Convention, the International Law Commission reasoned:

The Commission also felt that the right to revoke the notice [of withdrawal] is really implicit in the fact that it is not to become effective until a certain date and that it should be left to the parties to lay down a different rule in the treaty in any case where the particular subject-matter of the treaty appeared to render this necessary. ${ }^{64}$

The drafting history of the Vienna Convention appears to suggest that Article 65 applies as lex generalis where a treaty does not derogate from that principle with a lex specialis withdrawal rule. In other words, the treaty in question does not cover

${ }^{61}$ See supra n. 57.

${ }^{62}$ Art. 65(1) Vienna Convention on the Law of Treaties.

${ }^{63}$ Arts. 54 and 56 Vienna Convention on the Law of Treaties.

${ }^{64}$ The United Nations International Law Commission Draft Articles on Treaties with Commentaries, 'Yearbook of the International Law Commission', Vol. II (1966) p. 264. 
situations that fall under Article 54(a) Vienna Convention: 'The termination of a treaty or the withdrawal of a party may take place: (a) in conformity with the provisions of the treaty. ${ }^{65}$ Article 50 TEU would appear to clearly fall under Article 54(a) of the Vienna Convention and thus quite possibly outside the scope of Article 68 of the Vienna Convention. The same would apply to Article 67 of the Vienna Convention which refers back to Article 65 and regulates, at a technical level, the instruments that trigger the Article 65 procedure.

\section{The Court falls into its own 'intention trap'}

Regardless of whether Articles 65 and 68 even apply in this situation, it is beyond dispute that the two articles refer to 'invalidity, termination, withdrawal from or suspension of the operation of a treaty, ${ }^{66}$ i.e. they do not refer to withdrawal intentions. Article 68 also specifically refers to '[a] notification or instrument provided for in articles 65 or $67^{\prime}$, while no intentions to withdraw are mentioned. If the intention to withdraw were a legal concept separate from the act of withdrawal itself, as the Court had decided elsewhere in Wightman ${ }^{67}$ and derived from Minister for Justice and Equality v RO, ${ }^{68}$ Article 50 TEU could not prima facie lie within the ambit of Article 68 Vienna Convention, as the latter does not deal with intentions, but only with actual withdrawal and withdrawal notifications. This perhaps offers additional proof that the way the Court deals with the word intention - in both Wightman and Minister for Justice and Equality $v R O$ - is simply untenable.

\section{The CONSTITUTIONAL TOOLS}

It is probably fair to say that Article 50 was inserted into the TEU as a typical contractual mechanism which enables a contracting party to withdraw. The Court did not confine itself to the textual-contractual reading, however. The judgment recalled that:

According to settled case-law of the Court, that autonomy of EU law with respect both to the law of the Member States and to international law is justified by the essential characteristics of the European Union and its law, relating in particular to the constitutional structure of the European Union and the very nature of that law. ${ }^{69}$

\footnotetext{
${ }^{65}$ Art. 54(a) Vienna Convention on the Law of Treaties.

${ }^{66}$ Arts. 65 and 68 Vienna Convention on the Law of Treaties.

${ }^{67}$ Wightman, supra n. 1, para. 49.

${ }^{68}$ See supra n. 35.

${ }^{69}$ Wightman, supra n. 1, para. 45.
} 
The judgment went on to argue that 'the interpretation of a provision of EU law requires that account be taken not only of its wording and the objectives it pursues, but also of its context and the provisions of EU law as a whole, ${ }^{70}$ that 'treaties have as their purpose the creation of an ever closer union among the peoples of Europe, and ... that the European Union aims to eliminate the barriers which divide Europe', ${ }^{71}$ recalling 'the importance of the values of liberty and democracy, ${ }^{72}$ the fundamental status of EU citizenship, and that 'any withdrawal of a Member State from the European Union is liable to have a considerable impact on the rights of all Union citizens. ${ }^{73}$

The EU is a constitutional polity; withdrawal from it cannot simply be equated with withdrawal from a treaty regime. While withdrawal from an ordinary treaty of international law implies the severance of contractual relations between the withdrawing state and the other parties, withdrawal from the EU treaties implies separation from a complex overarching system of public law. ${ }^{74}$ As such, an exit from the $\mathrm{EU}$ is functionally akin to secession; it is not a simple severance of contractual obligations. ${ }^{75}$ The term secession needs to be used with caution; the EU is not a state, and one might do well to use the term separation instead. Nevertheless, given the complexity of the EU legal order, as the Court recalled, ${ }^{76} \mathrm{EU}$ withdrawal leads to legal problems that resemble those that arise when secession occurs, e.g. regarding the continuation of citizenship rights, succession of treaty obligations, relations with third states, and various financial settlements. ${ }^{77}$ While Article 50 textually follows the contractual logic of a treaty withdrawal mechanism, this contractual mechanism is odd in the context of functional secession from a constitutionalised legal order.

\section{Democracy and secession}

To continue the secession analogy, it might be useful to depart from Wightman to illustrate the issue from a broader comparative constitutional law perspective and understanding of the nature of the democratic process in the context of separation

${ }^{70}$ Ibid., para. 47.

${ }^{71}$ Ibid., para. 61.

${ }^{72}$ Ibid., para. 62.

${ }^{73}$ Ibid., para. 64.

${ }^{74} C f$ ECJ 5 February 1963, C-26-62, NV Algemene Transport- en Expeditie Onderneming van Gend \& Loos, p. 12, arguing that what is now the TEU is 'more than an agreement which merely creates mutual obligations between the contracting states'.

${ }^{75}$ See J. Vidmar, 'Brexit, Democracy, and Human Rights: The Law between Secession and Treaty Withdrawal', 35 Wisconsin Journal of International Law (2018) p. 425 at p. 440.

${ }^{76}$ See supra nn. 70-73.

${ }^{77}$ See Vidmar, supra n. 75, p. 429-433 and p. 440. 
from a constitutionalised legal order. Such a contextualisation is also warranted by the self-imposed role of the Court of Justice as the EU's Constitutional Court. ${ }^{78}$

There is one judicial authority that has addressed the problem of secession and democratic decision-making in a comparable process: the Supreme Court of Canada, in its landmark decision on the 1998 Quebec Reference, with several eminent legal scholars acting as amici curiae. ${ }^{79}$ In Quebec, the Supreme Court of Canada rejected an understanding of democracy simply as majority rule, ${ }^{80}$ stressing the importance of democratic deliberation and negotiation. ${ }^{81}$ The Supreme Court held that a referendum vote in favour of secession would not create a legal entitlement to independence under either Canadian constitutional law or international law. ${ }^{82}$ The principle of democracy, one of the principles that underpin the Canadian Constitution, nevertheless requires that the will of the people not be ignored. ${ }^{83}$ A pro-secession vote would create an obligation to negotiate the future legal status of the territory concerned, although this might or might not result in its independence. It could also result in greater autonomy or a looser association with Canada.

The Supreme Court of Canada furthermore noted that several groups within Quebec were not necessarily in favour of secession, e.g. the aboriginal peoples and linguistic minorities represented in the Province. ${ }^{84}$ According to the Court, Quebec's path to independence could not be just and legitimate under such circumstances, even if supported by a (narrow) majority of its residents. ${ }^{85}$ The reasoning of the Supreme Court of Canada clearly rejected the notion that democracy is a simple majority rule by which $50 \%$ plus one vote decides without further discussion. ${ }^{86} \mathrm{~A}$ referendum is, rather, a mechanism of deliberative democracy.

\section{Fixing the faulty 'secession' mechanism}

The aforementioned contractual reading of Article 50 TEU is quite different from the reasoning in the Quebec case. If the two-year Article 50 timeframe were seen as the period prior to the non-unilaterally revocable drop of the blade of a guillotine,

\footnotetext{
${ }^{78}$ See generally B. Vsesterdorf, 'A Constitutional Court for the EU?', 4 International Journal of Constitutional Law (2006) p. 607.

${ }^{79}$ The Supreme Court of Canada, 20 August 1998, [1998] 2 SCR 217, Reference re Secession of Quebec [hereinafter: The Quebec case].

${ }^{80}$ Ibid., para. 67.

${ }^{81}$ Ibid., para. 68.

${ }^{82}$ Ibid., para. 155 .

${ }^{83}$ Ibid., para. 88 .

${ }^{84}$ Ibid., para. 96.

${ }^{85}$ Ibid., para. 67.

${ }^{86} \mathrm{Ibid}$.
} 
it would need to be concluded that the mechanism was not compatible with a process of democratic deliberation. This is because the exiting state has no knowledge, at the moment it gives notice, of the terms that will apply when it exits. Suppose the UK had (hypothetically) decided to stay in the EU since it had concluded that Brexit would undermine the Good Friday Agreement, ${ }^{87}$ taking into account the fact that Northern Ireland had voted overwhelmingly in favour of remaining in the EU. Pursuant to the Quebec deliberative model, particular regard would need to be paid to the concerns of affected minorities. ${ }^{88}$ An obligation to exit once notice has been given is hardly compatible with similar ideals. The legal framework of non-unilateral revocability simply favours majoritarian decision-making; it fails to accommodate democratic deliberation during the process of negotiating the full exit parameters after these parameters have become known. Indeed, if no unilateral U-turn were possible, it would be quite futile to engage in a deliberative democratic process post-notification.

The Wightman judgment explicitly acknowledges the importance of the democratic process, reasoning that a member state should not 'be forced to leave the European Union despite its wish - as expressed through its democratic process in accordance with its constitutional requirements - to reverse its decision to withdraw and, accordingly, to remain a Member of the European Union' ${ }^{89}$ This pronouncement inter alia acknowledges that the democratic process may continue unabated even after notification to exit has been given. The act of reconsidering the original decision to exit is, thus, not an act of anti-democracy ${ }^{90}$ but an integral part of the democratic process.

Reversibility of secession would appear to be a quite natural feature of national constitutional models. In Quebec, the Supreme Court of Canada said that a vote would only trigger deliberation - not an obligation to achieve any specific result; hence, Quebec was under no obligation to secede. ${ }^{91}$ In Scotland, while a 2014 vote in favour of independence would have triggered a process of secession, ${ }^{92}$ it is difficult to imagine that Scotland would have had an obligation to secede even if

\footnotetext{
${ }^{87}$ The Belfast Agreement [The Good Friday Agreement] (10 April 1988), at <assets.publishing. service.gov.uk/government/uploads/system/uploads/attachment_data/file/136652/agreement.pdf>, visited 1 May 2019.

${ }^{88}$ The Quebec case, para. 96.

${ }^{89}$ Wightman, supra n. 1, para. 66 (emphasis added).

${ }^{90} \mathrm{Cf}$ 'Theresa May: Brexit deal rejection risks democratic "catastrophe", Politico (13 January 2019), at <www.politico.eu/article/theresa-may-brexit-deal-rejection-risks-democratic-catastrophe/>, visited 1 May 2019.

${ }^{91}$ See supra n. 80.

${ }^{92} \mathrm{See}$ 'Agreement between the United Kingdom Government and the Scottish Government on a referendum on independence for Scotland' [The Edinburgh Agreement] (15 October 2012), at <www.webarchive.org.uk/wayback/archive/20170701045319/www.gov.scot/About/Government/ concordats/Referendum-on-independence>, visited 1 May 2019. See also 'Scottish Independence
} 
public opinion had shifted once the secession parameters became known (e.g. no automatic EU membership and no monetary union with the UK). ${ }^{93}$

When the constitutional instruments of a polity are at the same time international treaties, the conflict between contractual and constitutional principles becomes rather complicated. The Court of Justice has sprung into action here as the EU's Constitutional Court to fix the faulty Article 50 mechanism, which was textually drafted as a treaty withdrawal clause but is inoperative as a mechanism for severance from a constitutionalised legal system. The Court has effectively decided to treat an exit from the EU as a functional secession - without using that term of course ${ }^{94}$ - rather than as mere treaty withdrawal.

The judicial constitutional fix of the contractual Article 50 mechanism has created some imbalance, however. It is much easier to retract a notification than to extend the deadline. The former can be done unilaterally; the latter requires unanimity. Although it is arguable whether revocation should be classified as a constitutional mechanism, extension remains a mechanism of treaty law. Wightman indeed fails to completely assuage the treaty law/constitutional law tension inherent to Article 50. Secession mechanisms are very rarely found in constitutional systems. Article 50 remains, in many respects, a treaty withdrawal mechanism, although in some aspects it can be interpreted with a constitutional touch.

The judgment has established that 'Article 50 TEU pursues two objectives ... [i] enshrining the sovereign right of a Member State to withdraw from the European Union and [ii] establishing a procedure to enable such a withdrawal to take place in an orderly fashion. ${ }^{95}$ In other words, the two-year period is intended to give both sides a reasonable period to negotiate an orderly withdrawal, at the same time guaranteeing the withdrawing state that it cannot be kept in the $\mathrm{EU}$ against its wishes. This is still somewhat more reminiscent of a treaty rather than a constitutional mechanism. Unilateral revocability adds, however, to the constitutional puzzle which ensures that a state can still deliberate and change its mind on the basis of the democratic process ${ }^{96}$; 'secession' from the EU legal order does, after all, have far-reaching consequences for the state and EU citizens. ${ }^{97}$

Referendum Act 2013, at <www.legislation.gov.uk/asp/2013/14/pdfs/asp_20130014_en.pdf>, visited 1 May 2019.

${ }^{93}$ See J. Vidmar, 'The Scottish Independence Referendum in an International Context', 51 Canadian Yearbook of International Law (2013) p. 259 at p. 279-282.

${ }^{94}$ See supra nn. 70-73.

${ }^{95}$ Wightman, supra n. 1, para. 56.

${ }^{96}$ Ibid., paras. 66 and 67.

${ }^{97}$ Ibid., para. 64. 


\section{Conclusion}

This analysis has focused on three main issues: the Court's interpretation of the word intention in Article 50 TEU; the Vienna Convention-based argument to corroborate its conclusion; and the constitutional argument. The constitutional argument rejects a purely contractual reading of Article $50 \mathrm{TEU}$ and treats it in certain respects as a mechanism for separation (functional secession) from a constitutionalised legal order. The Court has attempted to fix a faulty treaty-law mechanism which did not textually reflect the constitutional nature of the EU treaties, arguably creating more breathing space for the democratic process and deliberation, even after an exit notification has been given. The mere fact of giving an Article 50 notification does not create an obligation to exit.

Noting the autonomy of EU law, the Court has, nevertheless, paid considerable attention to the principles of treaty law. This was accomplished in two ways. The Court interpreted the term intention in Article 50 as, by definition, unilaterally revocable; intentions may change. In doing so, the judgment uncritically adopted the reasoning of the Advocate General who had drawn an analogy with the tenets of contract law. ${ }^{98}$ This analysis has argued that that analogy was highly problematic and not supported by the general theory and principles of either contract or treaty law. Furthermore, the judgment provided an additional Vienna Convention-based argument that is far from persuasive. It is at least debatable whether Article $50 \mathrm{TEU}$ notifications fall within the scope of Article 68 of the Vienna Convention, even more fundamentally, whether the Court rightly resorted to invoking the Vienna Convention. In the final analysis, the Court's argument, which was intended to be corroborative, in fact, undermines the Court's own reasoning regarding the legal effect of an intention.

Wightman was an attempt to apply a judicial fix to a faulty treaty withdrawal procedure that also operated as a constitutional secession mechanism. Although the Court's constitutional reasoning was not exactly controversial, the judgment itself was, however, quite controversial in that the Court failed to adequately address the admissibility concerns or explain why the case was not entirely hypothetical in nature. The Court's contract law analogies and its approach to the Vienna Convention were not entirely convincing, either. The pursuit of the Court's constitutionalist agenda should not be understood to mean that EU law, of necessity, exists in a legal vacuum. While EU law may well be considered an autonomous legal system sui generis, this does not necessarily imply that legal science sui generis should declare that the Vienna Convention has sui generis effects on non-parties and that the intentions of treaty parties can be accorded a sui generis escape clause, since 'intentions may change'.

\footnotetext{
${ }^{98}$ The Wightman Opinion, supra n. 36, para. 98.
} 